\title{
Dasein's Fulfillment: The Intentionality of Authenticity
}

\section{Leslie MacAvoy}

McGill University

The reader who attempts a hermeneutic understanding of Heidegger's Being and Time (SZ) has traditionally faced two notable challenges.' The first is that SZ is an incomplete text; the two published divisions represent approximately one third of the overall work as it is projected in Heidegger's introduction (SZ 39 40). The second challenge is that Heidegger published very little in the years preceding the appearance of SZ. The primary barometer of his thinking during this period is found in the manuscripts of his lecture courses and in his students' notes. Since much of this material has only been published in the last twenty years, access to this work has historically been limited.

These lacunae have made it difficult to situate SZ both within the context of Heidegger's early thought, and relative to the question which guides his entire philosophical endeavor-namely the Seinsfiage or the question of the meaning of Being. This is the question with which Heidegger begins his investigation in SZ (SZ 2-19), and it is meant to frame the discussion in the extant two divisions dealing with the Being of Dasein. Due to the incomplete nature of the text, however, it is easy to overlook that this discussion of Dasein is to be understood against the horizon of the Seinsfrage. Moreover, in the absence of further evidence of Heidegger's thinking leading up to this point, there is little to remind the reader of Heidegger's concern with the Seinsfiage during this period of his philosophical development.

These factors have fostered two general tendencies in traditional Heidegger interpretation. First, the observation is often made that Heidegger's early work is concerned with the Being of Dasein while his later work deals with Being in a broader sense. This view de-emphasizes the continuity in Heidegger's early and later thought, 2 and seems untenable upon consideration of Heidegger's early lecture courses which make it clear that Being was an early 
philosophical preoccupation. ${ }^{3}$ The lack of attention to the importance of the Seinsfiage in Heidegger's early work contributes to a second tendency, namely a decontextualization of SZ relative to this question. That is, the two published divisions are often interpreted independent of the inquiry into the Seinsfiage which frames them. The result of such a move is that $\mathrm{SZ}$ is often interpreted as a text of existentialism-a position which has serious implications for how Heidegger's concepts of authenticity and inauthenticity come to be understood. It is with these concepts and their relationship to Dasein's subjectivity that I am primarily concerned.

In recent years, with the publication of an increasing number of the lecture courses from the 1920s and early 1930s, the larger context of Heidegger's philosophical endeavor during this period is becoming more apparent. Important work on these early texts is being done which illustrates not only the unity of Heidegger's thought, but also the enormous impact that the thinkers most influential for him at the time-including Aristotle, Dilthey, Husserl, and Augustine-have had on his work. ${ }^{4}$ This more recent scholarship not only tends to undermine the position which would strongly separate the early Heidegger from the later Heidegger, it also provides a richer context for understanding SZ itself. Nevertheless, the textual specificity of SZ has not been re-examined in the light of the new material we now have at our disposal.

Clearly, a detailed re-interpretation of Heidegger's text is a task that belongs to a much larger project. My aim here is to propose a way of rethinking the concepts of authenticity and inauthenticity in relation to Dasein's subjectivity in light of Heidegger's critical engagement with Husserl's phenomenology, as documented in his 1925 lecture course, The History of the Concept of Time. To this end, I have structured the paper in three parts. The first outlines the traditional existentialist interpretation of authenticity and inauthenticity and its more sophisticated contemporary counterpart, the voluntarist interpretation. The second part considers Heidegger's analysis of the contributions of phenomenology as represented in HCT and the significance of the Seinsfrage. In the third, I discuss the importance of HCT for our understanding of SZ and in particular for our understanding of the concepts of authenticity and inauthenticity. 
The first two divisions of SZ are commonly referred to as the "Dasein analytic" or "existential analytic" because they inquire into the Being of the entity called Dasein. Dasein is distinct from other entities in that its Being is an issue for it [geht um]; that is, it bears a relationship to its Being, and this comportment toward its own Being is constitutive of what it is to be Dasein (SZ 12). This gives rise to two features which are ontologically distinctive of Dasein. Firstly, Dasein's essence lies in its existence; secondly, its Being is characterized by "mineness" |Jemeinigkeit] (SZ 42). The first feature indicates that the essence of the entity Dasein does not lie outside of or prior to its existence but is in fact constituted by that existence. The relationship to its Being which is constitutive of Dasein can only be enacted existentially-Dasein's existence constitutes its Being. The second feature indicates that Dasein is not indifferent to its Being but rather views its Being as belonging to it; thus Dasein's Being is something personal.5 The term "Dasein" literally means " $D a$-sein", a Being-there, signifying that in its Being, Dasein is always already situated. This is why Dasein's Being is known as a Being-in-the-world. ${ }^{6}$ This situatedness pertains to the two ontologically constitutive features just described. To say that Dasein's essence lies in its existence is to say that its existence in a concrete situation (its there) is constitutive. To say that this Being is always mine is to say that it always belongs to someoneto a concrete, identifiable, existing entity. Although the term "Dasein" is also used to designate a particular entity, it is more appropriate to say that "Dasein" names the Being which belongs to that entity and which never is except in that entity.

In the first division, Heidegger discusses Dasein in its everydayness, often understood as its inauthenticity. ${ }^{7}$ In the second he discusses Dasein's becoming authentic, where inauthenticity is Dasein's Being in the mode of not-Being itself and authenticity is its Being in the mode of Being itself. This paradoxical formulation is not exclusive to Heidegger but is shared with traditional philosophical reflections on alienation and its overcoming, as well as on the differences between the modes of being which pertain to potentiality or possibility and actuality. ${ }^{8}$ How one understands 
authenticity and inauthenticity in more concrete terms, however, depends a great deal upon how one understands this self which Dasein can both be and not-be.

The existentialist reading picks up on Heidegger's use of the language of existentialism and largely interprets the text through a theoretical framework defined by the catchphrase "existence precedes essence". 9 This slogan expresses the existentialist view that human beings exist first, and only out of this existence do they construct their essence. Thus, the fact that they exist is contingent and something for which they are not responsible, but who or what they are is something they create themselves. This is in opposition to other philosophical positions which maintain that essence is prior to material existence. So, the existentialist reads the two constitutive features of Dasein in the following terms: that Dasein's essence lies in its existence is understood to mean that Dasein creates its essence through its existence, that it is the author of its Being; that Dasein's Being is in every case mine is taken to mean that since this Being which I create is mine, I am the author of it and so am responsible for it. In this view, inauthenticity amounts to avoiding responsibility for one's own self-creation, to renouncing authorship and allowing others to assume that role. The classic example is that of unreflectively allowing social norms and practices to dictate one's behavior and activity. Authenticity, on the other hand, would involve renouncing the domination of others and assuming responsibility for oneself. The existentialist understanding of Dasein is implicit in those interpretations which maintain that, in inauthenticity, Dasein is dominated by others (das Man) and that to achieve authenticity Dasein must pull itself away from das Man and take charge of its existence. That Dasein alone can be responsible for its existence is said to be revealed to it in its Being-towards-death, which reveals its finitude and the fact that only Dasein can live its life.10

The central point in the existentialist interpretation which I find particularly problematic is the association of inauthenticity with Dasein's Being-with others (Mitsein), and the overcoming of this inauthentic dependence with a radical individuation and appropriation of Dasein's mineness in Being-towards-death." This view somewhat overstates the tension between Mitsein and Being- 
towards-death, and does not adequately take into consideration the role of Dasein's historicality in authenticity. More recent scholarship has argued against this existentialist reading largely on textual grounds, claiming that the complexity of the relationship between authenticity and inauthenticity has not been appropriately understood and that the role of Dasein's Being-with others as an essential existential structure has been blurred.12 The existentialist position reverses the traditional priority of essence and existence, and in reading Heidegger through this rubric, maintains that Dasein is responsible for creating its Being or essence. However, Heidegger does not share this view. He maintains that Dasein's essence is its existence. Rather than reversing the priority of essence over existence, he collapses the distinction. Dasein does not create its essence; its essence is its Being-Dasein, and this essence is something which it cannot choose; rather Dasein is burdened with it. Once having come into existence, Dasein must take over the task of that existence and become responsible for its Being, but it is never absolutely responsible for it. In becoming authentic, Dasein does not disentangle itself from its history and from others in order to become its own foundation. Rather, it makes its existence its own by allowing itself to be appropriated by that which conditions it. The existentialist reading ascribes to Dasein a capacity to create its own foundations-which Heidegger is at pains to demonstrate it does not have-and consequently characterizes authenticity in terms which are somewhat misleading. The result is a failure to capture the extent to which Dasein's subjectivity differs from the theories of subjectivity which precede it and from which Heidegger strives to differentiate himself (SZ 114-17, 317-23).

A similar difficulty is to be found in another, more nuanced approach to Heidegger's text which I will call the "voluntarist reading." Unlike the existentialist reading, the voluntarist position acknowledges that there are aspects of Dasein's existence which condition it and determine its essence as Dasein, and it grants that Dasein cannot be self-founding in the way that the existentialists maintain. In this sense, the voluntarist reading reflects a more careful understanding of Heidegger's text. The central claim of the voluntarist position is that authenticity is achieved through an act of the will, which is located in Dasein's resolution to be open to 
appropriating its Being and becoming its foundation in its "wanting to have a conscience" (SZ 295-301). The most notable proponent of this view is Michael Zimmerman, who identifies this moment of voluntarism in Heidegger's text in order to support the claim that Heidegger's early work remains imbedded in a fairly traditional conception of the subject as agent, albeit a situated and conditioned one. He maintains that this conception of the subject is only overcome in the later work. ${ }^{13}$

Since the voluntarist interpretation reads Dasein's self primarily in terms of agency and the exercise of the will, it views the ontologically constitutive features of Dasein's Being in similar terms. That Dasein's essence lies in its existence is understood in terms of activity: Dasein's essence lies in its willing. Furthermore, its mineness is to be associated with the fact that who it is, is to be determined by what it wills. This understanding of subjectivity stresses the same self-creation which characterizes the existentialist reading. Both readings emphasize a subjectivity in which authentic activity originates in the subject and is directed outward towards objects. Inauthenticity, by contrast, would be characterized by a certain passivity or inactivity.

The existentialist and voluntarist readings, then, share a particular view of subjectivity as agency which is enacted through the subject's exercising its will. Heidegger's notion of resoluteness [Entschlossenheit] is generally cited as the justification for this interpretation. I would, however, argue against placing undue emphasis on the role of the will in Heidegger's account of authentic subjectivity because that subjectivity is defined in terms of both active and passive moments. Although he claims that resoluteness is only phenomenologically given in a resolution, it is nevertheless distinguishable from a resolution-a decision or act of the will (SZ 298). Resoluteness is wanting to have a conscience [Gewissenhaben-wollen], and this is an authentic disclosedness of Dasein.14 Wanting to have a conscience is similarly ambiguously active and passive. One cannot will to have a conscience because the call of conscience is not chosen: "Indeed the call is precisely something which we ourselves have neither planned nor prepared for nor voluntarily performed, nor have we ever done so. 'It' calls, against our expectations and even against our will" (SZ 275). One can at 
most be open to hearing the call.15 The hearing of the call or appeal is a disclosedness which depends upon finding oneself called, as well as understanding that one is called. Dasein's potentialityfor-Being, its Seinkönnen, is attested through the call of conscience, and throughout his discussion of this phenomenon, Heidegger emphasizes what we might call the "middle-voicedness" of this disclosure: an ambiguity between active and passive moments. 16 This ambiguity is evident throughout his treatment of hearing and listening, as well as in the specific claim that Dasein lets itself be called forth to its ownmost possibility. ${ }^{17}$ To be sure, Dasein chooses itself (SZ 287), but the passive constructions that Heidegger uses throughout these passages suggest that this choosing must be understood within a context in which Dasein is also, as it were, chosen. Thus, we cannot read resoluteness purely in terms of an act of the will. Dasein achieves authenticity at least as much through its openness to being appropriated by its possibilities and to being drawn into a situation.

It is problematic to attribute to Dasein a subjectivity founded on agency and the will, as both the existentialist and the voluntarist readings do, because it is not clear that Heidegger's account of disclosedness in general and the authentic disclosedness of Dasein in particular fully corroborates this interpretation. In my view, greater appreciation of the more complicated account of subjectivity which he offers can be gained through increased attention to his work as a phenomenological project and to the importance of this project for understanding Dasein's subjectivity.

The inquiry of SZ must be situated within a broader philosophical context, specifically that of Heidegger's engagement with Husserl's phenomenology. The key to Heidegger's critique of Husserl lies in his thematization of the Seinsfrage. When we come to understand why this question is so important for Heidegger, as well as the nature of its relation to the Dasein analytic, we will approach a deeper understanding of the subjectivity which belongs to Dasein, both in its authenticity and in its inauthenticity. We will come to understand Dasein's Being in terms of intentionality. 
Heidegger's complex relationship to Husserl is most explicitly articulated in HCT, the 1925 lecture course in which Heidegger directly addresses Husserl and the phenomenological tradition. In this text, the Seinsfrage is introduced against the background of a more extended discussion of the contributions and shortcomings of phenomenology. In particular, Heidegger is concerned with the necessity of submitting intentionality to phenomenological analysis. The sections of HCT where he pursues this endeavor closely resemble large sections of SZ, and indeed, HCT is generally seen as a draft of SZ.18 For this reason, the text provides a useful point of mediation between the language of phenomenology and intentionality, and the more specifically Heideggerian language of SZ.19

Husserl is concerned with the problem of knowledge which traditionally focuses on the correlation between real things in the world and our ideas of them. In such a schema, truth lies in a correspondence between reality, or the physical world, and what we know, or the psychic domain. One must then have a theory of how it is possible for such a resemblance to be effected through the mediation of the senses. The empiricist argues that data from sensations are assembled by the understanding into representations from which ideas can be reached through a process of abstraction. Husserl argues against this view in Logical Investigations in his critique of psychologism. ${ }^{20}$ Alternatively, one might adopt an idealist approach, as exemplified for instance by Kant. To a certain degree this position can be seen to sidestep the problem by denying that knowledge is or ought to be of noumena. Kant maintains that we cannot have knowledge of the things in themselves, but only as they appear to consciousness, only in so far as they are phenomena. Husserl agrees that we can only have knowledge of phenomena, and he further insists that the only meaningful understanding of "the thing itself" is the phenomenon in the first place. Hence, he is not particularly worried about the inaccessibility of the noumenon. However, Husserl does not seem to agree with Kant's view that the categories through which the understanding grasps objects are projected or brought to bear by consciousness in the way that Kant suggests. Rather he maintains that phenomena 
already show themselves in terms of these categories, as confirmed by our experience in apprehending objects. In this way, he hopes to combat the claim that knowledge in an idealist framework is subjective, not objective. In some sense we can think of Husserl's phenomenology as an attempt to negotiate a position between empiricism and idealism.

In Heidegger's view, phenomenology has made three important philosophical contributions: intentionality, categorial intuition, and a particular understanding of the a priori. Intentionality is always a directedness towards an intentional object, and this "directedness towards" is the structure of lived experience; it is immediate (HCT 30). The intentional object is not a physical object "out there" in the world which the subject must apprehend and bring within its interiority as knowledge; rather, the intentional object is a phenomenon. It shows itself as what it is in its Being; it gives meaning. What I experience in lived reality are not brute objects, but objects that have significance. Intentionality is my comportment toward these objects relative to their significance and meaning.

In the sixth of his Logical Investigations, Husserl asks about meaning: where does it lie? how is it given? He identifies two general groups of acts-expressive acts and intuitive acts-and determines that meaning lies in neither the one nor the other, but in the unity of both. Expressive acts (such as judgments) refer to some meaning; they are referential or signifying, a projection from the subject toward an object. Intuitive acts are acts of apprehension in which the object gives some sort of meaning to the subject. The directionality of the intuitive act is opposite to that of the expressive act. Both types of acts, however, bear a relationship to meaning: both give meaning [sinngebend].

Most of the acts with which we typically associate meaning are expressive acts. Taken on their own, however, these acts are merely empty intentions because they refer to objects without those objects necessarily being intuitively, and therefore immediately, given. Heidegger's example is a conversational reference to some object-a bridge in Marburg. In so far as one merely refers to the bridge without an explicit intuitive apprehension of it, the intention remains empty. However, the meaning expressed in the empty 
intention can be confirmed through an intuitive act. Such an attestation fulfills the intention by providing evidence for it in a more immediate way. The intuitive act, in giving more immediately what is presumed in the expressive act, demonstrates the truth of the expression (HCT 49).21 One way in which this empty intention of the bridge can be fulfilled is by conjuring up a mental image of the bridge; still another way is by actually standing before the bridge and perceiving it. In the first case, the bridge is self-given, given in its Being. In the second, it is bodily given as well as self-given (HCT 41). There are many different kinds of intentions; each contains a particular tendency toward fulfillment which is related to the nature of the intention: i.e. perception is fulfilled through perception, feeling through feeling, and so on (HCT 44). It is important to emphasize that Heidegger views intentionality as the structure of lived experience; thus, when intentions are fulfilled-that is, when evidence is provided for them through an act of intuitionthis fulfillment is experienced as lived (HCT 48-50).

The intuition which fulfills the empty intention of an expressive act is categorial intuition, a form of "seeing" that belongs to intentionality but which should not be confused with simple perception. Simple perception is associated with sensory input, and categorial intuition is a "second order" intuition because it is founded upon simple perception.22 Since expressive acts express the meaning or Being of an object, an intuition which fulfills such an act must be an intuition of meaning or Being. But simple perception cannot perceive meaning or Being because neither is accessible to mere sensation. Consequently, an intuition capable of fulfilling such an intention must be something more than simple perception: this is categorial intuition. ${ }^{23}$ That Being is intuitively given, as opposed to subjectively projected, importantly establishes the objectivity of Being despite the fact that it is not accessible to simple perception. 24

The problem categorial intuition is intended to resolve might be made clearer by way of example. Normally we maintain that the truth of a particular assertion can be verified by checking the evidence given through perception. So, the statement, "the chair is yellow" is verified by looking at the chair in question to see if, in fact, it is yellow. But the statement "the chair is yellow" asserts 
the Being-yellow' of the chair, whereas sensory perception does not perceive the Being-yellow, but only the yellow. Technically then, perception cannot provide the evidence necessary to prove the truth of the assertion. So where does one find the evidence for the $\mathrm{Be}$ ing-yellow? Is it merely something that we subjectively project onto the object? No. Both Husserl and Heidegger maintain that just because the Being-yellow of the chair cannot be verified by the senses does not mean that Being-yellow is merely a subjective quality. The Being-yellow of the chair has an objectivity, which is provided through categorial intuition founded upon simple perception.

Through categorial intuition, objects are given as meaningful wholes; these meaningful wholes provide evidence for the various acts of signification that we perform. 25 Philosophy has traditionally characterized the distinction between simple perception and categorial intuition by means of the standard differentiation between sensibility and understanding, or matter and form. According to Heidegger, these characterizations miss the point of categorial intuition as intuition. Categories are precisely not added on to sense perceptions by the subject but are intuited, given by the objects themselves (HCT 70-71): that is, the categories in terms of which objects of intuitive acts appear, are given in intuition. They need not be directly and explicitly accessible, however. They may only become apparent as categories through a series of phenomenological reductions which strip away the intuitive content of the act to leave behind the ideative structure. 26

In so far as these categories shape the meaning which is intuitively given in any particular apprehension, they are still $a$ priori and objective. Traditionally, the a priori which pertains to the categories has been understood as prior to all experience-and thus absolute in some sense or located in pure subjectivity or consciousness independent of objective, empirical experience. As we have seen, however, categorial intuition shifts the location of the categories from something provided by the understanding to something given by the object through intuition. However, it is important to note that categories are not to be found in the object as given through simple perception. In so far as what is given in an act of categorial intuition can be taken as evidence for various ex- 
pressive acts or acts of signification, this implies that acts of categorial intuition occur in terms which correspond to those of acts of expression. In fact, Heidegger maintains that we tend to "see" and understand things as they have already been "seen," expressed, and understood (HCT 56). Although the categories implied in categorial intuition are prior to any given experience, they are not absolutely prior (HCT 72-75).27

Despite the contributions of phenomenology with respect to intentionality, categorial intuition, and the a priori, Heidegger maintains that it has failed to submit the Being of intentionality to analysis. Specifically, phenomenology has not sought to lay bare its own possibility - the Being of phenomena at all, the Being of intentionality which makes phenomena possible, or the Being of the entity who is intentional. Husserl's approach is to exact a series of reductions in which successive facets of lived experience are bracketed in order to reach the essence of the intentional object. 28 The purpose of this bracketing is to make the entity show itself in its Being (HCT 99); this occurs in two reductive moments. The first is the transcendental reduction in which my immersion in the stream of life experiences is bracketed so that I can now attend to the structure of those experiences. The second is the eidetic reduction in which the concretia of experiences are bracketed, stripping away that which makes them individual and particular, to leave only their ideative structure (HCT 100). What is left is the pure field of consciousness (HCT 100).

Heidegger's question to Husserl's phenomenology is: Does the concept of the pure field of consciousness address the question of the Being of consciousness at all? Heidegger thinks it does not. According to Heidegger, Husserl never submits consciousness to phenomenological scrutiny, although the Being of consciousness is presupposed by all of his investigations. The result is that his phenomenology is not properly grounded (HCT 108). For Heidegger, some of Husserl's reductions are problematic because they bracket aspects of the phenomenon of consciousness which are actually essential to it.

In the reduction we disregard precisely the reality of the consciousness given in the natural attitude 
in the factual human being. The real experience is suspended as real in order to arrive at the pure absolute experience. The sense of the reduction is precisely to make no use of the reality of the intentional; it is not posited and experienced as real. We start from the real consciousness in the factually existing human, but this takes place only in order finally to disregard it and to dismiss the reality of consciousness as such. In its methodological sense as a disregarding, then, the reduction is in principle inappropriate for determining the being of consciousness positively. The sense of the reduction involves precisely giving up the ground upon which alone the question of the being of the intentional could be based (admittedly with the aim of then determining the sense of this reality from the region now secured). (HCT 109)

Husserl's reductions remove the immediacy of intentional experience, most importantly with respect to its mineness (HCT 109). In abstracting away all that individuates experience, one is left with intentional acts only in terms of their "what"-content; how' intentional acts are in terms of being the structure of lived experience is thus overlooked.29 That which makes the experience lived-namely the existence of an intentional comportment on the part of some existing entity toward some specific object-is precisely what is taken out of account (HCT 110). Yet Husserl emphasizes this starting point in lived experience in maintaining that the intentional does not pertain to a relation between psychic and physical reality.

Heidegger concludes that phenomenology to date has neglected two important questions: first, the question of the Being of intentionality; and second, the question of the meaning [Sinn] of Being itself (HCT 115). The first asks what it is to be intentional. Intentionality only occurs in the entity which is intentional, namely Dasein. Thus, if we want to understand intentionality as the structure of lived experience, we must examine Dasein and the structures of its lived experience-what Heidegger in SZ will term its existentiality. ${ }^{30}$ The second question involves the meaning or sense 
of Being. What do we mean when we talk about Being? In what sense do we understand it?31 According to Heidegger, the pursuit of the question of the meaning of Being requires a phenomenological inquiry into the Being of the entity to whom Being becomes manifest; this entity is Dasein. Furthermore, it requires an inquiry into this entity with particular attention to those structures through which Being becomes manifest; this is Dasein's intentionality. Thus, the answer to the second question is to be sought in the answer to the first.

\section{III}

Heidegger begins SZ with the following words:

Do we in our time have an answer to the question of what we really mean by the word "being"? Not at all. So it is fitting that we should raise anew the question of the meaning of Being. But are we nowadays even perplexed at our inability to understand the expression "Being"? Not at all. So first of all we must reawaken an understanding for the meaning of this question. Our aim in the following treatise is to work out the question of the meaning of Being and to do so concretely. Our provisional aim is the Interpretation of time as the possible horizon for any understanding whatsoever of Being. (SZ 1)

In this passage and in the text which follows, Heidegger stresses that the Seinsfrage is the question with which he is concerned, yet he says remarkably little about its significance. ${ }^{32}$ It is in this regard that HCT is extremely helpful and provides important background to Heidegger's point of departure in SZ.

It is clear that in Heidegger's view an analysis of Dasein's Being is necessary in order to get at the meaning of Being. But why? Heidegger maintains that an implicit understanding of Being is operative in intentional comportment: it is presumed in every encounter, in every assertion, in every expression, in every use of the 
“is". Dasein understands Being much in the same way that empty intentions refer to the meanings which they express: it understands Being without grasping Being. And since intentionality is the structure of lived experience, this proto-understanding of Being is operative in Dasein's existence; indeed it is an integral part of it. Heidegger believes an examination of Dasein's Being, and the structures of its existence, will be instructive in illuminating the meaning of Being because he believes that he can expose the understanding of Being with which Dasein always already operates through a fulfillment of Dasein's empty intention of its own Being.

Heidegger's point will be that Dasein understands its own Being, not in terms of substance, but in terms of temporality. Dasein understands itself as finite, finite in the sense of being mortal, of being limited with respect to time. Upon establishing this, Heidegger will examine Dasein's everyday way of understanding itself in order to demonstrate that it is actually temporal in origin. He will also go to lengths to demonstrate that the very sense of Being as substance, as presence-at-hand, is also derivative of temporality-specifically of the temporal mode of the present. Heidegger will argue that the sense of Being which underlies Dasein's understanding of its own Being and the Being of objects is not space but time. To prove this, Heidegger must pursue an analysis of Dasein's Being. He must show how Dasein understands its own Being, not only in everydayness-where Dasein only emptily intends its Being - but also in authenticity where what is only indeterminately understood in everydayness is more fully grasped. My suggestion is that the first two divisions of SZ aim to accomplish this task.

If Dasein is an entity whose Being is an issue for it, then it always comports itself toward its Being in one way or another; its Being is always an intentional object for it. In everydayness, Dasein comports itself towards its own Being in the manner of an empty intention; it refers to itself purely expressively. To experience the truth of its Being, Dasein would require evidence of that truth. Such evidence could only be given in an intuitive act. Such an intuitive act occurs when Dasein's Being is brought before it and apprehended in its anxious Being-towards-death. Here, Dasein experiences its Being in the most immediate fashion, the empty 
intentionality which characterizes Dasein's everydayness is fulfilled, and Dasein becomes authentic. In SZ Heidegger goes to lengths to show that Dasein's inauthenticity is always a privative mode of its authentic Being-in-the-world and to illustrate that every "fallen" way of Being-Dasein is actually a way of Being-Dasein but only in the mode of not-Being it. It is not its Being in the sense that in inauthenticity [Uneigentlichkeit] Dasein's Being is not its own, or it is not the Being which is most proper to it. ${ }^{33}$ These claims substantiate the view that both authenticity and inauthenticity have the same intentional object-namely Dasein's Being-but that in authenticity that intention is full (Dasein is its Being), while in inauthenticity it is empty (Dasein is not its Being). ${ }^{34}$

Since the language of intentionality found in HCT is not particularly apparent in SZ, how can we substantiate this view? Heidegger does not begin the opening passages of SZ with the claim that Dasein is the entity which is intentional, but rather that Dasein is the entity who questions (SZ 7). He further states that all questioning has the following structure: there is always something asked about, someone or something interrogated, and something one hopes to find out by asking (SZ 5). In the case of the Seinsfiage, the entity who asks the question is the same as the entity queried, namely Dasein, because it is Dasein who has an indeterminate understanding of Being as part of its Being. ${ }^{35}$

The whole discussion at the opening of SZ, which occurs in terms of questioning, closely resembles those sections in HCT in which Heidegger offers an analysis of the structure of the question and its relationship to "the questioning entity (Dasein)" (HCT 14448). In HCT these passages follow Heidegger's discussion of phenomenology's neglect of the Seinsfiage and the Being of intentionality. The concern with questioning, then, is not isolated to $\mathrm{SZ}$, but is bound up with issues raised in HCT, issues which are articulated in the language of intentionality.

More importantly, Heidegger maintains in HCT that the entity who is intentional has an indeterminate understanding of Being which is presumed in every intentional comportment in which it understands the Being of its intentional object; this understanding is given in an indeterminate way in questioning. 36 Heidegger repeats this idea in SZ when he claims that all questions contain within 
them an indeterminate understanding of that about which they ask (SZ 5-6). Such an understanding is necessary in order to even formulate the question, to seek anything at all. The understanding must be indeterminate, however, otherwise it would not be necessary to ask the question; one would already have the answer. Questions, then, reflect a proto-understanding of that about which they ask, which resembles the indeterminate "comprehension" of the intentional object exhibited by an empty intention.

Questions, we may say, are fulfilled, not simply by any response whatsoever, but by the response which conforms in a particular way to the question which elicits it. Some responses answer the question; others do not; the potential of a particular response to be an answer lies in the question to which it responds. Indeed, it is the proto-understanding of that about which the question asks that allows the questioner to have a sense of whether or not the question has been answered. The relationship between question and response is not unlike that already noted between empty and fulfilled intentions. The empty intention points at something which is given through the intuitive act which fulfills it; only when this evidence is given can the truth of the expressive act be seen in a positive light. Moreover, the original expressive act contains within it the possibility of its fulfillment, in the sense that it sets the parameters for the particular intuitions which may fulfill it. Although Heidegger does not explicitly refer to the response which Dasein receives to its questioning, one can understand the attestation provided by what is given in the call of conscience as evidence to support this view (SZ 267-301). Indeed, the phenomenon of conscience can be seen as proof of the fact that Dasein is always questioning itself, even if only implicitly. The call of conscience brings Dasein before itself in its anxious Being-towards-death because in conscience Dasein calls itself to itself. Dasein is "summoned to itself-that is, to its ownmost potentiality-for-Being" (SZ 273), and this is done by the caller who, it turns out, is Dasein's Self, ${ }^{37}$ but a self which Dasein is not in its everydayness. ${ }^{38}$ Heidegger makes it clear that the call of conscience is the mechanism by which Dasein's "potentialityfor-Being-its-Self," which it already is as a possibility, is attested (SZ 268). In this attestation, Dasein's Being is authentically disclosed. It thus represents a fulfillment of the intention which 
constitutes Dasein's everydayness. It is important to recognize here that this fulfillment does not imply completion, since Dasein's Being is one of openness and possibility. A fulfillment of its intention of itself exposes Dasein to this openness in an immediate fashion. Such a fulfillment is Dasein's authenticity.

Dasein is the entity for whom its Being is an issue. It bears a relationship to its Being, which means that its Being is an intentional object for it, and this manifests itself in the very structures of Dasein's existentiality. But that Dasein's Being is an issue for it also implies that Dasein is concerned with its existence; its existence matters to it, which is why it asks about it. To say that Dasein's essence lies in its existence is to say that this concern with its Being, this asking about it, is worked out in its very existing. Dasein's existence and the structures thereof demonstrate this concern with its Being. To say that Dasein's Being is always characterized by mineness-that it is always in every case mine-means that every factical entity whose Being is Dasein is concerned with its Being, with its existence, and that the factical specificity of this concern and the questioning which produces it are essential. As we have seen above, Heidegger appears to be responding directly to Husserl, who reduced intentional acts to a level of abstraction which obscured the fact that intentionality is experienced personally in the immediacy of lived experience. If Dasein's self is intentional according to the structures of its existentiality, then authenticity and inauthenticity must pertain to ways of Being this intentional self in modes of Being and not-Being it, respectively. As I have already noted, in inauthenticity Dasein is its intentionality in the mode of not-Being it, namely in an empty and merely referential fashion. In authenticity, Dasein is its intentionality in the mode of Being it, in the way of a fulfilled intention.

In the existentialist view the self creates its essence through the process of its existing; it is the author of its essence. Inauthenticity would be giving this responsibility over to another; authenticity would be to assume it oneself. The voluntarist view is similar, except that it focuses on the exercise of the will. In both cases, what distinguishes authenticity from inauthenticity is something which comes from the self, the subject, and which projects outward onto the world, appropriating it in some way or 
another. But the directionality associated with the intentional self is somewhat different. The act of expression or signification, which is outward in its orientation, is a feature of both authenticity and inauthenticity. In authenticity evidence is provided for the intentional "object" through intuition; the intentional emptiness of subjective expression is fulfilled by the intuited object. Intuition, understood phenomenologically, does not have the same unidirectionality as the projection associated with agency in the existentialist-voluntarist accounts. Categorial intuition, as we have stressed above, is not a function of subjectivity projecting something onto the object. It is the objective giving itself of the object; it is founded upon simple perception. Consequently, the intention is fulfilled (and authenticity achieved) not through a subjective act of the will, but through a more passive reception of the object as it gives itself to categorial intuition. What fulfills the intention comes not from the self, but from the other. This holds true in the paradigm of questioning as well, where the response which fulfills the question comes from the other. ${ }^{39}$

If Dasein is defined as the entity for whom its Being is an issue, this definition must apply to Dasein in any of its modes. Dasein is concerned with and asks about its Being in both authenticity and inauthenticity. What differentiates them is whether the response that is given really answers the question, whether it really provides that which the question seeks. We must remember that the understanding of what one is asking about-which guides the questioning -is rather indeterminate and vague. Often a sense of clarity regarding the question is only apparent after the question has been answered; the sense that a particular response is adequate often sheds a great deal of light on what the question was really about. The questioning in which Dasein is engaged in its existence shares in this characteristic; that Dasein questions is often apparent only in the sense of fulfillment which accompanies the receiving of an adequate response. This sense of fulfillment is the feature which definitively distinguishes authenticity and inauthenticity.

The central issue for Heidegger in both SZ and HCT is the Seinsfiage, and hence it is worth pausing to reflect on this very question. It is one thing to understand the Dasein analytic formally relative to the question which lies behind it, but we should also 
consider it in terms of its significance. Heidegger maintains that the philosophical tradition by and large has failed to question Being qua Being. Because the tradition has tended to understand Being exclusively in terms of beings, or entities, Being is not viewed as an issue worthy of questioning; it simply has not appeared questionable.

What this implies is that we have not found ourselves to be questioned by Being; it has not shown itself (explicitly at least) as an enigma, as something whose meaning is in question. The questionableness of something throws itself back on the one to whom it appears questionable, thereby challenging her to ask the question and to seek an answer. The experience of being challenged points to the openness of that entity, Dasein, to being questioned and to being able to question. Dasein is the only entity for whom the Seinsfiage is a possibility because it is the only entity which bears a relationship to its Being. In this sense, it has priority over other entities. ${ }^{+0}$ The Seinsfiage itself has a certain priority relative to other questions: ontologically, because of its importance with respect to other types of inquiry; and ontically, because of its importance in Dasein's existence. 41

Because of Dasein's ontic and ontological priority, its Being is a point of access into the question of the meaning of Being; fundamental ontology must be sought through the existential analytic of Dasein (SZ 13). Dasein asks itself about its Being in order to find out the meaning of that Being. That Dasein asks the question implies both that it already has a relation to that Being, and that this relation implies a particular-though indeterminateunderstanding. That Dasein asks itself the question implies that, in a sense, it already has an answer to the question, albeit an obscured one. In asking itself about its own Being, Dasein hopes to bring to light the meaning of Being overall. Heidegger aims to show that the horizon against which Being can appear as a phenomenon is time. Given this, we can understand the existential analytic as follows. The first division, which deals with Dasein in its average everydayness, discloses Dasein as the entity which has a preontological understanding of Being. Heidegger must demonstrate both who Dasein is such that asking the Seinsfrage is a possibility of its Being, and that Dasein does indeed have anything like an 
understanding of Being, albeit a mostly empty one. The first division maps out the formal indications with respect to Dasein which must be confirmed in the second division, where Heidegger must show how Dasein's empty intention of its own Being can be fulfilled. He must demonstrate how Dasein's Being can be disclosed to it in a way that gives evidence for what it emptily intends in everydayness. This disclosure must occur through a type of phenomenological reduction in which Dasein's Being is uncovered and becomes more explicitly an issue for it. It occurs when the meaning of Dasein's own Being is thrown into question against the horizon of its own death. Being-towards-death is what phenomenologically reveals Dasein's Being to it as such. The meaning of Dasein's Being is mortality, which derives its sense from a more general understanding of Being in terms of temporality. 42

This understanding of Dasein's subjectivity and of the concepts of authenticity and inauthenticity emerges when the Dasein analytic is situated relative to the project of the Seinsfrage. This has been done here through a reading of Heidegger's more extended discussion of phenomenology in HCT. This reading of Dasein's authenticity in terms of empty and fulfilled intentionality, which is only further refined in Heidegger's characterization of Dasein as the entity who questions, highlights the features of Dasein's subjectivity which differentiate it significantly from the more traditional metaphysical subjectivity promoted by the existentialistvoluntarist position.

\section{Notes}

1. Martin Heidegger, Sein und Zeit (Tübingen: Niemeyer, 1961); Being and Time, trans. John Macquarrie and Edward Robinson (New York: Harper \& Row, 1962). All references will be cited as SZ, and the page numbers will refer to the German edition.

2. The idea of Heidegger I versus Heidegger II is introduced by Father William Richardson. In the preface to Richardson's work, Heidegger accepts this distinction only with qualification. See William 
Richardson, Heidegger: Through Phenomenology to Thought, 3rd ed. (The Hague: Martinus Nijhoff, 1974).

3. See Martin Heidegger, Dic Grundprobleme der Phänomenologie, ed. F. W. von Herrman (Frankfurt: Klostermann, 1975); The Basic Problems in Phenomenology, trans. Alfred Hofstadter (Bloomington: Indiana University Press, 1982). Martin Heidegger, Prolegomena zur Geschichte des Zeitbegriffs, ed. Petra Jaeger (Frankfurt: Klostermann, 1979); The History of the Concept of Time, trans. Theodore Kisiel (Bloomington: Indiana University Press, 1985). These texts will be referred to as BPP and HCT, respectively.

4. Particularly helpful here are Theodore Kisiel, The Genesis of Heidegger's "Being and Time" (Los Angeles: University of California Press, 1993) and Theodore Kisiel and John van Buren, eds., Reading Heidegger from the Start: Essays in His Earliest Thought (Albany: SUNY Press, 1994). This last volume contains many good essays on this topic. See also Theodore Kisiel, "On the Way to Being and Time: Introduction to the Translation of Heidegger's Prolegomena zur Geschichte des Zeitbegriffs," Research in Phenomenology 15 (1985): 193-226; Theodore Kisiel, "The Genesis of Being and Time," Man and World 25 (1992): 21 37; Rudolf A. Makreel, "The Genesis of Heidegger's Phenomenological Hermeneutics and the Rediscovered "Aristotle Introduction' of 1922," Man and World 23 (1990): 305-20; John van Buren, "The Young Heidegger and Phenomenology," Man and World 23 (1990): 239-72.

5. "Because Dasein has in each case mineness [Jemeinigkeit], one must always use a personal pronoun when one addresses it: 'I am', 'you are"”(SZ 42).

6. It is important to keep in mind that this notion of situatedness is not be understood with respect to geometrical space, but with respect to contexts of significance.

7. There is some discussion as to whether everydayness is actually inauthentic or just an undifferentiated mode between authenticity and inauthenticity. See for example, Robert Dostal, "The Problem of 'Indifferenz' in Sein und Zeit," Philosophy and Phenomenological Research 43 (Sept. 1982): 43-58.

8. That Heidegger shares this with such traditions does not, however, imply that it is appropriate to understand authenticity and 
inauthenticity in terms of such reflections. Heidegger does not think Dasein is somehow "more" itself in authenticity (SZ 43). He also does not think that there is some originary self which is lost in inauthenticity and which is to be regained through authenticity; Dasein's foundationlessness is precisely the basis of its existential guilt (SZ 280-89).

9. This language is largely borrowed from Kierkegaard. Kisiel documents that Kierkegaard's works were quite popular in Germany at the time and notes that Heidegger seems to have resisted this vocabulary for some time, as it does not appear in the earlier drafts of the text (Genesis of Heidegger's "Being and Time" 316, 394-95, 397, 419 and 489). For a much more detailed discussion of the evolution of the language in Heidegger's work in the 1920s, see Theodore Kisiel, “'Existenz' in Incubation: Underway Toward Being and Time" in From Phenomenology to Thought, Errancy and Desire, ed. Babette Babich (Dordrecht: Kluwer, 1995) 89-114. However, it is undeniable that there are many similarities between Heidegger's concepts of das Man and Being-towards-death and Kierkegaard's discussion in such works as The Present Age, The Sickness unto Death and The Concept of Dread. See for example Harrison Hall, "Love and Death: Kierkegaard and Heidegger on Authentic and Inauthentic Existence," Inquiry 27 (July 1984): 179-97.

10. For a good discussion of the existentialist reading and its shortcomings, see Lawrence Vogel, The Fragile "We": Ethical Implications of Heidegger's "Being and Time" (Evanston: Northwestern University Press, 1994) 28-48.

11. This tendency to associate inauthenticity with Being-with others crops up in such texts as Michael Theunissen's Der Andere: Studien zul. Sozialontologie der Gegenwart (Berlin: de Gruyter, 1977); The Other: Studies in the Social Ontology of Husserl, Heidegger, Sartre and Buber, trans. Christopher Macann (Cambridge: MIT Press, 1984) and Richard Wolin's The Politics of Being: The Political Thought of Martin Heidegger (New York: Columbia University Press, 1990).

12. See for example, Jay A. Ciaffa, "Toward an Understanding of Heidegger's Conception of the Interrelation between Authentic and Inauthentic Existence," Journal of the British Society of Phenomenology 18 (Jan. 1987): 49-59; Charles Guignon, "Heidegger's 'Authenticity' Revisited," Review of Metaphysics 38 (Dec. 1984): 321-39; Abraham Mansbach, "Heidegger on the Self, Authenticity and Inauthenticity," Iyyun 
40 (Jan. 1991): 65-91; Norman K. Swazo, "Heidegger on Being-with Others," Dialogue (Milwaukee) 30 (Oct. 1987): 1-9.

13. See Michael E. Zimmerman, The Eclipse of the Self: The Development of Heidegger's Concept of Authenticity (Athens, OH: Ohio University Press, 1981). See especially pp. 41, 54, 76, 98. Although, for Zimmerman, Dasein is "said to exist because [it] hold[s] open the temporal horizons in which beings can be manifest" (33), the issue for him is still ultimately one of choice. "We can choose to be this temporal-historical openness in an authentic or inauthentic way" (33). Although Zimmerman is always careful in his analysis to draw attention to those aspects of Heidegger's text which seem to provide evidence against the allegation of voluntarism, he never explains why these do not dissuade him from his ultimate conclusion. His overall point is to show that the voluntarist overtones and moments of Heidegger's early work are residue from a metaphysical subjectivism which is left behind as Heidegger's concept of authenticity matures. Zimmerman pursues this point in a somewhat more moderate form in a later article. He maintains that the voluntarist overtones of SZ give it its "existentialist flavor", but that they are overcome in the later work (although he admits that Heidegger was already looking for alternative ways of expressing his thought in the 1920s). According to Zimmerman, the voluntarist aspect is the distinguishing feature between early and later Heidegger. See Michael Zimmerman, "Heidegger's 'Existentialism' Revisited," International Philosophical Quarterly 24 (Sept. 1984): 219-36 and Michael Zimmerman, "Heidegger's New Concept of Authentic Selfhood," The Personalist 57 (Spring 1979): 198-212. This linking of Heidegger's work with voluntarism also occurs in Wolin (35-40). A similar spin is given to authenticity in Roy Martinez, "An 'Authentic' Problem in Heidegger's Being and Time," Auslegung 15.1 (1989): 1-20, and in Golomb's chapter on Heidegger. See Jacob Golomb, In Search of Authenticity: From Kierkegaard to Camus (New York: Routledge, 1995). For an argument against Zimmerman, see Guignon and Mansbach.

14. "The disclosedness of Dasein in wanting to have a conscience, is thus constituted by anxiety as state-of-mind, by understanding as projection upon one's ownmost Being-guilty, and by discourse as reticence. This distinctive and authentic disclosedness, which is attested in Dasein itself by its conscience-this reticent self-projection upon one's ownmost Being-guilty, in which one is ready for anxiety-we call "resoluteness" (SZ 296-297). 
15. "Understanding the appeal" means "wanting to have a conscience". This does not mean that one wants to have a "good conscience", still less that one cultivates the call voluntarily; it means solely that one is ready to be appealed to" (SZ 288).

16. Disclosedness in general is characterized by both active and passive moments, as exemplified in the contrast between understanding and Befindlichkeit.

17. "When Dasein understandingly lets itself be called forth [das verstehende Sichvorrufenlassen] to this possibility, this includes it becoming free for the call-its readiness for the potentiality of getting appealed to [Angerufenwerdenkönnen]" (SZ 287) and "in understanding the call, Dasein lets its ownmost Self take action in itself in terms of that potentiality-for-Being which it has chosen [läßt das Dasein das eigenste Selbst aus seinem gewählten Seinkönnen in sich handeln" (SZ 288).

18. See Kisiel, Genesis of Heidegger's "Being and Time." Kisiel traces the development of Heidegger's thought from the Kriegsnotsemester (KNS) 1919 through its various stages until it reaches the formulation that appears in SZ. Kisiel discusses Heidegger's reading of phenomenology, the Scholastics, Christian mystics, and Aristotle-among othersand offers a treatment of the three drafts of SZ. The first draft appeared as an introduction to a text on Aristotle which was never published; the second was the lecture course HCT; the final draft is the extant version of SZ itself.

19. Caputo offers another account of Heidegger's relationship to Husserl using BPP as a basis for discussion. See John Caputo, "The Question of Being and Transcendental Phenomenology: Reflections on Heidegger's Relationship to Husserl," Research in Phenomenology 7 (1977): 84-105. It should perhaps be noted that, at the time of Caputo's article, Prolegomena zur. Geschichte des Zeitbegriffs had not yet been published.

20. Edmund Husserl, Logical Investigations, trans. J.N. Findlay (London: Routledge, 1970).

21. Intentions can also admit of varying degrees of fulfillment.

22. This implies that categorial intuition cannot operate in the absence of some perceptual intuition-past, present or imagined. So in the 
example just described, the empty intention of the bridge can be fulfilled through a mental image of it in the absence of any perception of the bridge only because it (or a representation of it) was at one time perceived.

23. On the "more" in which Being consists vis-à-vis simple perception, see Richard Kearney, "Surplus Being: The Kantian Legacy" in From Phenomenology to Thought, Errancy and Desire, ed. Babette Babich (Dordrecht: Kluwer, 1995) 71-87.

24. For a very good discussion of this topic, see Jiro Watanabe, "Categorial Intuition and the Understanding of Being in Husserl and Heidegger" in Reading Heidegger: Commemorations, ed. John Sallis (Bloomington: Indiana University Press, 1993) 109-17.

25. Though the example here pertains to assertorial judgments, this is only one type of intention.

26. It is through phenomenological reduction that the inessential is bracketed, permitting the disclosure of the essential structure which usually remains concealed.

27. This point is critical because if the categories are prior, but not absolutely prior, it implies that they are historically constituted. This is an important link not only with the idea of time as the horizon of Being, but also with the entire project of hermeneutics.

28. Part of Heidegger's criticism, as I have just noted, is that this process has not been directed at intentionality or Dasein, but has focused primarily on other entities. However, Husserl's project presupposes an entity like Dasein.

29. "It disregards the fact that the acts are mine or those of any other individual human being and regards them only in their what. It regards the what, the structure of the acts, but as a result does not thematize their way to be, their being an act as such. It is solely concerned with the whatcontents of the structures, the structure of the intentional as the basic structure of the psychic, the what-contents of the constitution of this structure, the essence of the what of comportments, the variations of their selfdirectedness and the what-content of their constructional relationships, but not the essence of their being" (HCT 109). In SZ Heidegger is very critical of the philosophical tradition's treatment of Being in terms of present-at-hand "what"-contents. 
30. On intentionality in SZ see Harrison Hall, "Intentionality and World: Division I of Being and Time" in Cambridge Companion to Heidegger, ed. Charles B. Guignon (Cambridge: Cambridge University Press, 1993) 122-40.

31. That this is indeed what Heidegger means by this question can be confirmed by examining his discussion of the Seinsfrage in the opening of SZ (SZ 2-4). See also, HCT 114-15. Being does not consist in the disclosure of phenomena, it only shows itself in the manifesting of phenomena. Consequently, Being does not depend upon the intentional entity, but it does require intentionality in order to manifest itself. Heidegger would maintain that, in phenomenological terms, the Being of something is what is attested when evidence is given through an act of categorial intuition which shows the truth of an expressive act. The truth of the expressive act does not lie in the act of intuition, but is shown through what is given therein. The thing shows itself as being what it is in the fulfillment of the intention which expresses it. Being, then, is intimately connected with Being-true, and Being-true is in turn intimately connected with the phenomenon of intentionality. Given Heidegger's criticism of the tradition's understanding of Being as presence-at-hand, we should be wary of understanding Being as what is disclosed in the disclosure.

32. For a discussion of the Seinsfrage in Heidegger's work see Dorothea Frede, "The Question of Being: Heidegger's Project" in Cambridge Companion to Heidegger, ed. Charles B. Guignon (Cambridge: Cambridge University Press, 1993) 42-69. For a discussion (with different emphasis than mine) of the relationship between the task of fundamental ontology and the existential analytic, see Murray Miles, "Fundamental Ontology and Existential Analysis in Heidegger's Being and Time," International Philosophical Quarterly 34 (Sept. 1994): 349-59.

33. One might also cast this in Heidegger's language of possibility. Dasein's Being is a Seinkömmen, and so is a kind of Being-possible. In everydayness, Dasein understands possibility as something which exists outside of it and which befalls it. It does not see possibility as belong to its Being. Thus, it comports itself toward possibility without grasping itself as possibility (SZ 261-63).

34. This aids us in understanding Heidegger's claim that authenticity and inauthenticity are modes of Dasein's mineness (SZ 53). 
35. "It is peculiar to this entity [Dasein] that with and through its Being, this Being is disclosed to it. Understanding of Being is itself a determination of Being /eine Seinsbestimmtheit] of Dasein"(SZ 12). Note that Macquarrie and Robinson translate "Seinsbestimmtheit" as "a definite character".

36. "We thus have a very distinctive questioning inasmuch as in the content of the question, in what is asked for, what is asked for is itself what the questioning itself is. What is asked for in it, the sense of being, is thereby given in all indeterminacy, as indeterminate as only what is sought can be" (HCT 147).

37. "In conscience Dasein calls itself” (SZ 275).

38. "The caller is Dasein in its uncanniness ... the caller is unfamiliar to the everyday they-self" (SZ 276-277).

39. Though the other which calls Dasein in the call of conscience is Dasein's self, it is Dasein's self in its alterity. Even in the case where one asks oneself a question, there is a sense in which the self who asks is "other" than the self who answers, otherwise there would be no need for the question in the first place.

40. It has priority at the ontic level because it is the only entity who exists (i.e. comports itself toward Being) and at the ontological level because this existence is ontologically constitutive of this entity (SZ 8-15).

41. The question of the meaning of Being shows up ontically for Dasein as the question of the meaning of Dasein's Being. What is the meaning of existence in the face of that which questions it, namely death?

42. "Our analysis of Dasein [in the first division], however is not only incomplete; it is also, in the first instance, provisional. It merely brings out the Being of this entity, without interpreting its meaning. It is rather a preparatory procedure by which the horizon for the most primordial way of interpreting Being may be laid bare. Once we have arrived at that horizon, this preparatory analytic of Dasein will have to be repeated on a higher and authentically ontological basis" (SZ 17). 